\title{
Effect of application of filter cake and biogas manures on improving of some desertic soil properties and their implications on plants grown thereon. I. Effect on chemical and physical properties
}

\author{
Mahmoud A. M. Abdelal ${ }^{1}$, Mohamed E. Ali ${ }^{1}$, Esmat H. Noufal ${ }^{1}$ and Ali M. A. El-Nagar ${ }^{2}$ \\ ${ }^{1}$ Soils and Water Department, Faculty of Agriculture, Moshtohor, Benha University, Egypt. \\ ${ }^{2}$ Soil Department, Faculty of Agriculture, Cairo University, Egypt. \\ Corresponding author: esmat.noufal@yahoo.com
}

\begin{abstract}
The present investigation aims at studying the effect of application of biogas manure and filter cake (Filter mud), as a natural soil amendments, on improving some properties of desertic soils and their implications on barely plant grown thereon. A pot experiment was carried out at the greenhouse of soils and water department, Faculty of Agriculture, Benha University, Egypt, using perforated PVC pots of $5 \mathrm{~kg}$ capacity and barley (Hordum vulgare cv. Giza 123) as a test plant. Two surface soil samples $(0-30 \mathrm{~cm})$ differed in their texture and calcium carbonate content, were collected, to achieve these aims, from El-Hammam region, North-Western Coast of Egypt, to represent desertic soils. Biogas manure and filter cake (filter mud) were added at a rate of 0, 1, and $2 \%$ (w/w) and thoroughly mixed with the soil and incubated for two months at moisture content equivalent to field capacity. Ten grains were planted in each pot. Irrigation was done with tap water so as to reach the water holding capacity of the soil. After complete germination plants were thinned to 5 per pot. Macronutrients of N, P and K were added to all pots according to the rates equivalent to those recommended by the Ministry of Agriculture. The experimental design was factorial randomized complete block design with two factors, in three replicates. At maturity, plants were harvested and soil samples were taken from each pot for physical and chemical analyses. The obtained results show that:

1. The main effect of the rate of application of biogas manure and filter cake to the sandy loam soil (Soil 1) show that soil salinity significantly decreased at $\mathrm{R}_{1}(1 \%)$ while slightly increased due to the application of $\mathrm{R}_{2}(2 \%)$. However, application of biogas manure and filter cake to the loamy sand soil (Soil 2) significantly and progressively increased its salinity with the rate. There was a significant difference between the biogas manure and filter cake effect on soil salinity.

2. The main effect of the organic amendment shows that the application of both amendments significantly increased the organic matter content of the both soils and the increase due to the application of biogas manure was higher in the case of the sandy loam soil (S1) than that occurred due to the application of the filter cake, and vice versa occurred in the case of the loamy sand soil (S2).

3. The main effect of the rate of application of the both amendments shows that the CEC value significantly and progressively decreased in the sandy loam soil (S1), while it increased in the loamy sand soil (S2); the biogas manure was more effective than the filter cake in increasing the CEC value of the soil

4. Available N, P and K content significantly and progressively increased with increasing the rate of the applied amendment to both soils. There was a significant difference between the biogas manure and filter cake in increasing the available $\mathrm{N}, \mathrm{P}$ and $\mathrm{K}$ content in the two soils, where filter cake was more efficient than the biogas manure in this respect.

It could be concluded that application of biogas manure and filter cake improved the majority of soil properties and the improvement depends on the properties of the applied amendment, the application rate and the native soil properties. Filter cake was more efficient than the biogas manure in improving soil properties.
\end{abstract}

Keyword: Biogas manure, filter cake, calcareous soil, sandy soil, physical properties, chemical properties, barley plants.

\section{Introduction}

Land is the major permanent renewable resource and faces the greatest threat of degradation. Land degradation is often attributed to human causes (Gray, 1999; Misak et al., 2002). The United Nations Convention to Combat Desertification (UNCCD, 1994 and Gad and Abdel-Samie, 2000) defined desertification as land degradation in arid, semiarid and dry sub humid areas resulting from climatic variations and anthropogenic activities. It is synonymous with land degradation in dry lands, manifesting in vegetation loss, water and wind erosion, salinization of irrigated soils and soil compaction (Dregne, 2002; Tewari and Arya, 2005; Wessels et al., 2007 and Wessels et al., 2008 and D'Odorico et al., 2012). It was therefore hypothesized that desertification has effect on the soil organic carbon (SOC) (Abubakar and Eniolorunda, 2016). Generally, arid soils have poor quality due to very low levels of soil organic matter (Ravi et al., 2010). Currently, Egypt's population is 
confined to a fine strip of arable land along the Nile River, while deserts account for around $96 \%$ of Egyptian land (EEAA, 2007 and Ali, 2013). Land reclamation remains high on the agenda of the Egyptian Government and is supported directly or indirectly by international agencies (Bush, 2007). Desert reclamation is one of the priorities to compensate for the loss of agricultural land in Egypt (Aldabaa et al., 2010).

For the urgent need to meet food and dress demands in Egypt, more desert areas either sandy or calcareous have to be put under cultivation. Such soils are poor with respect to their physico-biochemical properties, soil water-plant relationships as well as their nutritional status.

Sandy soils are mainly infertile with poor physical chemical properties and require addition of organic manure (Foth, 1990 and Campbell et al., 2002) to improve their fertility. The productivity of sandy soils is mostly limited by their low capacity water for retained and nutrients due to excessive deep percolation losses, which reduce the efficiency of water and fertilizer use by plants. Organic manure increases structural stability and water retention of sandy soils (Nyamangara et al., 2001). So, soil conditioners have been recommended to be effective tools for increasing water holding capacity, reducing infiltration rate and cumulative evaporation and improving water conservation of sandy soils. In Egypt, improving sandy soils is considered as an important part of the agricultural security program. Sandy soils represent about $90 \%$ of the Egyptian soils. Such soils represent a great hope for the agricultural expansion.

Calcareous soil is defined as having the presence of significant quantities of free excess lime (calcium or magnesium carbonate) (El-Hady and AboSedera, 2006). Calcareous soils cover more than of $30 \%$ of the earth's surface and their $\mathrm{CaCO}_{3}$ content varies from a few percent to 95\% (Balba, 1989). Calcareous soils occur naturally in arid and semi-arid zones as well as in humid and semi-humid zones particularly where their parent materials is rich in $\mathrm{CaCO}_{3}$ (Brady, 1990). Organic and mineral soil amendments are soil improving agents. Among the natural soil conditioners, which have been used in Egypt for reclamation of sandy and sandy calcareous soils are organic manures and composts.

Organic and inorganic soil amendments are commonly added to soil for improving its physical and chemical characteristics which promote plant growth. Soil physical and chemical characteristics are affected by soil amendment and production system (Tejada and Gonzalez, 2004 and Aksakal et al., 2012)). Thus, the organic soil amendments are usually mixed with soil to provide the optimal physical and chemical environment (Yangyuoru et al., 2006) to the growing plants. It is now widely recognized that soil organic matter (SOM) plays an important role in soil chemical ( $\mathrm{pH}$, base saturation, salinity and CEC changes) and physical (bulk density, stabilization of soil structure and aggregate formation) properties (Yilmaz and Alagöz, 2010). Soil organic matter improves the physical, chemical and biological properties of soil, and crop residue recycling is an important factor influencing soil organic matter levels (Zia et al., 1993 and Watson et al., 2002).

According to El-Banna et al. (2011), in Egypt, barley is the effective choice in the risky conditions such as poor soils and newly reclaimed areas, which suffer from water shortage and water quality. Barley (Hordeum vulgare L.) is the main crop grown in a large scale in the North Coastal Region of Egypt and also in the newly reclaimed lands with saline soils and shortage of fresh water. Barley production area increased in the new reclaimed lands under different irrigation systems.

Thus, the main objective of the current study is to improve some physical and chemical properties of two desertic soils, differed in their calcium carbonate content, and their productivity through the application of filter cake and the biogas manure as natural amendments and the implications on barley plant growth and nutrient and uptake.

\section{Materials and Methods}

A pot experiment was carried out under the greenhouse conditions at Faculty of Agricultural, Soils and Water Department, Benha University, during winter season of 2015-2016 to assess the effect of applying the filter cake and biogas manure, as a natural soil conditioners, on some chemical and physical properties of the soils under study and their effect on the plants grown thereon. Two surface soil samples $(0-30 \mathrm{~cm})$, differed in their texture and calcium carbonate content, were collected from ElHammam region, North-Western Coast of Egypt, lies between latitudes $30^{\circ} 45^{\prime}-31^{\circ} 00^{\prime} \mathrm{N}$ and longitudes $28^{\circ} 30^{\prime} 29^{\circ} 00^{\prime} \mathrm{E}$. The North-Western Coast of Egypt (NWCE) represents one of the high priority regions for future development and is one of the main challenging regions for sustainable development. Filter cake or mud is one of the waste materials available from the industries of sugar can, composted and used as natural organic amendment.

The collected soil samples were air dried, crushed and sieved to pass through a $2 \mathrm{~mm}$ sieve. Physical and chemical properties of the studied soils, which were determined according to the methods cited by Klute (1986) and Page et al. (1982) are shown in Table 1. 
Table 1. Physical and chemical properties of the studied soils .

\begin{tabular}{|c|c|c|}
\hline 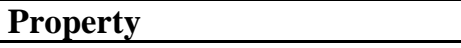 & Soil 1 & Soil 2 \\
\hline \multicolumn{3}{|c|}{ Particle size distribution } \\
\hline C. Sand (\%) & 27.87 & 30.40 \\
\hline F. Sand (\%) & 37.43 & 48.60 \\
\hline Silt (\%) & 30.65 & 14.00 \\
\hline Clay $(\%)$ & 4.05 & 7.00 \\
\hline Soil texture * & Sandy loam & Loamy sand \\
\hline Saturation percentage $(\%)$ & 47.90 & 30.60 \\
\hline Field capacity $(\%)$ & 24.41 & 5.49 \\
\hline Wilting point $(\%)$ & 2.76 & 0.33 \\
\hline Available water (\%) & 21.65 & 5.16 \\
\hline Bulk density $\left(\mathrm{Mg} \mathrm{m}^{-3}\right)$ & 1.24 & 1.59 \\
\hline Hydraulic conductivity $\left(\mathrm{cm} \mathrm{h}^{-1}\right)$ & 0.99 & 1.11 \\
\hline $\mathrm{OM}\left(\mathrm{g} \mathrm{kg}^{-1}\right)$ & 24.81 & 32.12 \\
\hline $\mathrm{CEC}\left(\mathrm{cmmol}_{\mathrm{c}} \mathrm{kg} \mathrm{soil}^{-1}\right)$ & 34.68 & 25.10 \\
\hline $\mathrm{Ca} \mathrm{CO}_{3}\left(\mathrm{~g} \mathrm{~kg}^{-1}\right)$ & 327.00 & 291.00 \\
\hline $\mathrm{pH}$ & 7.80 & 7.70 \\
\hline $\mathrm{EC}\left(\mathrm{dS} \mathrm{m} \mathrm{m}^{-1}\right)$ & 12.70 & 1.00 \\
\hline \multicolumn{3}{|c|}{ Soluble ions (mmolc $\left.\mathrm{L}^{-1}\right)$ (in Saturated soil paste extract) } \\
\hline $\mathrm{HCO}_{3}^{-}$ & 6.89 & 3.30 \\
\hline $\mathrm{CO}_{3}{ }^{2-}$ & 0.00 & 0.00 \\
\hline $\mathrm{Cl}^{-}$ & 63.63 & 3.13 \\
\hline $\mathrm{SO}_{4}{ }^{2-}$ & 56.16 & 3.85 \\
\hline $\mathrm{Ca}^{2+}$ & 36.61 & 5.88 \\
\hline $\mathrm{Mg}^{2+}$ & 21.76 & 2.30 \\
\hline $\mathrm{Na}^{+}$ & 65.35 & 1.66 \\
\hline $\mathrm{K}^{+}$ & 2.96 & 0.44 \\
\hline \multicolumn{3}{|c|}{ Available nutrients $\left(\mathrm{mg} \mathrm{kg}^{-1}\right)$} \\
\hline Available N & 129.5 & 66.5 \\
\hline Available P & 11.26 & 11.90 \\
\hline Available K & 688.00 & 526.00 \\
\hline
\end{tabular}

\section{The greenhouse experiment:}

Perforated PVC pots with dimensions of $10 \mathrm{~cm}$ depth and $25 \mathrm{~cm}$ diameter, and a capacity of 5 kilo gram were used in the current study. Each pot was uniformly packed with $5 \mathrm{~kg}$ of soil and incubated for two months at moisture content equivalent to field capacity. Filter cake and Biogas manure were added at a rate of 0,1 , and $2 \%$ and thoroughly mixed with the soil. Chemical and physical properties of the organic amendments used in the current study are shown in Table 2. Barely plant (Hordum vulgare cv. Giza 123) was used as a test plant. Ten grains were planted in each pot on November $1^{\text {st }} 2015$. Macronutrients of N, P and $\mathrm{K}$ were added to all pots according to the recommended dose of the Egyptian Ministry of Agriculture. Irrigation was done with tap water so as to reach water holding capacity of the soil (about field capacity). After complete germination plants were thinned to 5 per pot.

\section{Fertilization:}

$\mathrm{N}$ was added at $200 \mathrm{mg} \mathrm{N} \mathrm{kg}^{-1}$, while $\mathrm{P}$ and $\mathrm{K}$ were added at 15 and $50 \mathrm{mg} \mathrm{kg}^{-1}$, respectively. Fertilizer sources were ammonium sulphate, calcium superphosphate, and potassium sulphate. $\mathrm{N}$ was added in 3 doses $(20 \%$ at sowing, $40 \%$ with the first irrigation and $40 \%$ with the second irrigation) while $\mathrm{P}$ and $\mathrm{K}$ were added during soil preparation, immediately before seeding.

The experimental design was factorial randomized complete block design with two factors, in three replicates, as follows:

Factor A: Organic amendment $(\mathrm{O})$, two organic amendment as follows:

(i) Biogas manure $\left(\mathbf{O}_{\mathbf{1}}\right)$

(ii) Filter cake (Filter mud) $\left(\mathbf{O}_{2}\right)$.

Factor B: Rate of application ( $R)$, three rates as follows:

i. $\quad \mathbf{R}_{\mathbf{0}}$ : No application of amendment

ii. $\quad \mathbf{R}_{1} 1 \%$ organic amendment (w/w)

iii. $\quad \mathbf{R}_{2} 2 \%$ organic amendment (w/w)

At maturity, plant height, the number of tillers and spikes were recorded, then, plants were harvested. 
Soil analysis:

A sample of soil representing the soil used in the experiment before initiation of the experiment was analyzed for the main physical and chemical properties. After harvesting of plants undisturbed soil samples were taken for physical analysis. Also, soil samples were taken from each pot for chemical analysis.

Statistical analysis:-

Results were statistically analyzed according to Snedecor and Cochran (1980).

Table 2. Chemical and physical properties of the organic manures used in the current study.

\begin{tabular}{|c|c|c|}
\hline Properties & Biogas manure & Filter cake \\
\hline Moisture content (\%) & 19.1 & 9.65 \\
\hline Bulk density $\left(\mathrm{Mg} \mathrm{m}^{-3}\right)$ & 410.00 & 0.27 \\
\hline pH at (1:10 suspension) & 7.80 & 6.60 \\
\hline $\mathrm{EC}\left(\mathrm{dS} \mathrm{m}^{-1}\right)$ at $(1: 10$ suspension $)$ & 5.50 & 4.30 \\
\hline $\mathrm{CaCO}_{3}\left(\mathrm{~g} \mathrm{~kg}^{-1}\right)$ & 80.00 & 115.00 \\
\hline CEC (mmolc kg-1) & 155.94 & 451.39 \\
\hline Organic carbon $\left(\mathrm{g} \mathrm{kg}^{-1}\right)$ & 28.29 & 17.67 \\
\hline Organic matter $\left(\mathrm{g} \mathrm{kg}^{-1}\right)$ & 49.00 & 30.39 \\
\hline Total nitrogen $\left(\mathrm{g} \mathrm{kg}^{-1}\right)$ & 1.90 & 2.8 \\
\hline C: $N$ ratio & $15: 1$ & $6.31: 1$ \\
\hline Total P $\left(\mathrm{g} \mathrm{kg}^{-1}\right)$ & 11.50 & 18.40 \\
\hline Total K $\left(\mathrm{g} \mathrm{kg}^{-1}\right)$ & 8.00 & 10.50 \\
\hline
\end{tabular}

\section{Results and discussion}

1-Effect of application of organic amendments on soil properties:

a - Effect on chemical properties:

Results in Tables 3a, 3b and 3c show the effect of applying the biogas manure and filter cake on soil salinity, organic matter content and the CEC of the soil under study, respectively.

Concerning the effect on soil salinity (Table 3 a) , the main effect of the rate of application of biogas manure and filter cake at increased rate to the sandy loam soil (Soil 1) show that soil salinity significantly decreased at $\mathrm{R}_{1}(1 \%)$ while slightly increased due to the application of $\mathrm{R}_{2}(2 \%)$. However, application of biogas manure and filter cake at increased rate to the loamy sand soil (Soil 2) significantly and progressively increased its salinity with the rate. On the other hand, the main effect of the organic manure applications shows that there is a significant difference between the biogas manure and filter cake effect on soil salinity, where in the case of the sandy loam soil (Soil 1), the application of biogas manure slightly increased its salinity whereas the application of filter cake significantly decreased it. In the case of the loamy sand soil (Soil 2), application of the biogas manure and filter cake significant increased its salinity, and the increase in the case of application of the biogas manure was higher than the increase in the case of filter cake application.

Respect the effect of the organic amendments on the organic matter content of the soils under study (Table 3 b), the main effect of the rate of application shows that organic matter content in both soils significantly and progressively increased with increasing the rate of application. On the other hand, the main effect of the organic amendment shows that the application of both amendments significantly increased the organic matter content of the both soils. However, in the case of the sandy loam (S1) the increase $(11.15 \%)$ in organic matter content occurred due to the application of biogas manure was higher than the increase $(7.17 \%)$ occurred due to the application of the filter cake, compared with $\mathrm{R}_{0}$ and vice versa occurred in the case of the loamy sand soil (S2) where the filter cake increased the organic matter content by $(45.46 \%)$ whereas the biogas manure increased it by $(45.05 \%)$ compared with $\mathrm{R}_{0}$. On the other hand, the increase in the organic matter content in the loamy sand soil (S2) was higher than that of the sandy loam soil (S1), where the increase was $11.15 \%$ and $7.17 \%$ for the sandy loam (S1), and $45.05 \%$ and $45.46 \%$ for the loamy sand soil (S2) due to the application of biogas manure and filter cake, respectively.

As for the effect of application of the organic amendments under study on the CEC of the studied soils (Table $3 \mathbf{c}$ ), the main effect of the rate of application shows that the CEC value significantly and progressively decreased in the sandy loam soil (S1), while it increased in the loamy sand soil (S2) due to the application of the biogas manure and filter cake at increased rate. The increase in the CEC value of the loamy sand soil could be attributed to its high content of organic matter owing to the application of these organic amendments compared with the sandy loam soil.

The main effect of the organic amendments shows that there is a significant difference, in the value of the CEC obtained due to the application the biogas manure and filter cake. In the case of the sandy loam soil (S1) the filter cake amendment caused a high decrease by $\mathbf{1 4 . 2 2} \%$ in its CEC value whereas the biogas manure caused a decrease by $\mathbf{3 . 5 4} \%$ as 
compared with non application $\left(\mathrm{R}_{0}\right)$. In the case of the loamy sand soil (S1) the application of biogas manure and the filter cake increased its CEC value by $\mathbf{1 0 . 2 8} \%$ and $2.13 \%$ respectively, as compared with non application $\left(\mathrm{R}_{0}\right)$; and the increase was higher with the application of the biogas manure than with filter cake. There was an interaction effect between the organic amendment and the rate of application, where the application of filter cake at $\mathrm{R}_{1}(1 \%)$ decreased the CEC value of both soils then increased it with the application of $\mathrm{R}_{2}(2 \%)$. Application of biogas manure at increased rate decreased the CEC value of the sandy loam soil (S1), while increased that of the loamy sand soil (S2).

Table 3. Effect of application of biogas manure and filter cake as a natural organic amendments on the soil salinity $\left(\right.$ ECe dS m$\left.~_{-1}\right)$, organic matter content $\left(\mathrm{g} \mathrm{kg} \mathrm{soil}^{-1}\right)$ and CEC $\left(\mathrm{mmolc} \mathrm{g} \mathrm{kg}^{-1}\right)$ of a desertic soils. a: $\mathbf{E C}_{\mathrm{e}}$

\begin{tabular}{|c|c|c|c|c|c|c|c|c|}
\hline \multirow{4}{*}{$\begin{array}{l}\text { Organic } \\
\text { amendment (O) }\end{array}$} & \multicolumn{8}{|c|}{$\operatorname{ECe}\left(\mathrm{dS} \mathrm{m}^{-1}\right)$} \\
\hline & \multicolumn{4}{|c|}{ Soil (1) } & \multicolumn{4}{|c|}{ Soil (2) } \\
\hline & \multicolumn{8}{|c|}{ Rates of addition ( $R$ ) } \\
\hline & $\mathbf{R}_{\mathbf{0}}$ & $\mathbf{R}_{1}$ & $\mathbf{R}_{2}$ & Mean & $\mathbf{R}_{\mathbf{0}}$ & $\mathbf{R}_{1}$ & $\mathbf{R}_{2}$ & Mean \\
\hline $\mathrm{O}_{1}$ & 11.20 & 11.02 & 11.77 & 11.33 & 2.56 & 4.20 & 6.17 & 4.31 \\
\hline $\mathrm{O}_{2}$ & 11.20 & 9.67 & 10.70 & 10.52 & 2.56 & 3.72 & 4.16 & 3.48 \\
\hline Mean & 11.20 & 10.35 & 11.24 & & 2.56 & 3.96 & 5.17 & \\
\hline LSD at $5 \%$ & $\mathrm{O}=0.14$ & $\mathbf{R}=\mathbf{0 . 1 7}$ & $\mathbf{O} \times \mathbf{R}=\mathbf{0 . 3 0}$ & & $\mathrm{O}=0.08$ & $\mathbf{R}=\mathbf{0 . 0 6}$ & $\mathbf{O} \times \mathbf{R}$ & \\
\hline
\end{tabular}

B: OM

\begin{tabular}{|c|c|c|c|c|c|c|c|c|}
\hline \multirow{4}{*}{$\begin{array}{c}\text { Organic } \\
\text { amendment }(O)\end{array}$} & \multicolumn{8}{|c|}{ Organic matter content $\left(\mathrm{g} \mathrm{kg} \mathrm{soil}^{-1}\right)$} \\
\hline & \multicolumn{4}{|c|}{ Soil (1) } & \multicolumn{4}{|c|}{ Soil (2) } \\
\hline & \multicolumn{8}{|c|}{ Rates of addition ( $R$ ) } \\
\hline & $\mathbf{R}_{\mathbf{0}}$ & $\mathbf{R}_{1}$ & $\mathbf{R}_{2}$ & Mean & $\mathbf{R}_{\mathbf{0}}$ & $\mathbf{R}_{1}$ & $\mathbf{R}_{2}$ & Mean \\
\hline $\mathrm{O}_{1}$ & 33.59 & 38.43 & 39.86 & 37.29 & 22.04 & 35.44 & 38.42 & 31.97 \\
\hline $\mathrm{O}_{2}$ & 33.59 & 36.26 & 38.16 & 36.00 & 22.04 & 30.58 & 43.55 & 32.06 \\
\hline Mean & 33.59 & 37.35 & 39.01 & & 22.04 & 33.01 & 40.99 & \\
\hline LSD at $5 \%$ & $\mathrm{O}=0.26$ & $\mathbf{R}=\mathbf{0 . 2 6}$ & $\mathrm{O} \times \mathrm{R}=\mathbf{0 . 5 5}$ & & $\mathrm{O}=0.45$ & R 0.60 & $=\mathbf{O} \times \mathbf{R}$ & $=0.12$ \\
\hline
\end{tabular}

C: CEC

\begin{tabular}{|c|c|c|c|c|c|c|c|c|}
\hline \multirow{4}{*}{$\begin{array}{c}\text { Organic } \\
\text { amendment }(O)\end{array}$} & \multicolumn{8}{|c|}{ CEC $\left(\right.$ mmol $\left._{\mathrm{c}} \mathrm{kg} \mathrm{soil}^{-1}\right)$} \\
\hline & \multicolumn{4}{|c|}{ Soil (1) } & \multicolumn{4}{|c|}{ Soil (2) } \\
\hline & \multicolumn{8}{|c|}{ Rates of addition $(\mathrm{R})$} \\
\hline & $\mathbf{R}_{\mathbf{0}}$ & $\mathbf{R}_{1}$ & $\mathbf{R}_{2}$ & Mean & $\mathbf{R}_{\mathbf{0}}$ & $\mathbf{R}_{1}$ & $\mathbf{R}_{2}$ & Mean \\
\hline $\mathrm{O}_{1}$ & 40.68 & 40.64 & 36.40 & 39.24 & 43.58 & 48.91 & 51.70 & 48.06 \\
\hline $\mathrm{O}_{2}$ & 40.68 & 31.74 & 32.18 & 34.87 & 43.58 & 42.48 & 47.47 & 44.51 \\
\hline Mean & 40.68 & 36.19 & 34.29 & & 43.58 & 45.69 & 49.58 & \\
\hline LSD at $5 \%$ & $\mathbf{O}=0.18$ & $\mathbf{R}=0.22$ & $\mathrm{O} \times \mathrm{R}=\mathbf{0 . 3 8}$ & & $\mathrm{O}=0.14$ & $\mathbf{R}=0.24$ & $\mathbf{O} \times \mathbf{R}=$ & \\
\hline
\end{tabular}

\section{b. Effect on the available nutrient contents:}

Results in Tables $\mathbf{4 a}, \mathbf{4 b}$ and $\mathbf{4 c}$ show the effect of application of the studied organic amendments on the available nutrient contents of the soils under study. The main effect of the rate of organic amendment application shows that available N, P and $\mathrm{K}$ content in the studied soils significantly and progressively increased with increasing the rate of the applied amendment. The highest available N, P and $\mathrm{K}$ content was obtained due to the application of the highest rate of the applied amendment. This pattern of response occurred in both soils under study. However, the available $\mathrm{P}$ content in the loamy sand soil (S2) was higher than that of the sandy loam soil (S1); this could be attributed to the high content of $\mathrm{CaCO}_{3}$ in sandy loam soil compared with the loamy sand one.

The main effect of the applied amendment shows that there is a significant difference between the biogas manure and filter cake in increasing the available $\mathrm{N}, \mathrm{P}$ and $\mathrm{K}$ content in the two soils except with available $\mathrm{K}$ in the sandy loam soil (S1) where the difference was not significant. Also, the main effect of the applied amendment shows that the filter cake was more effective than the biogas manure in increasing the available nutrient contents except for available $\mathrm{K}$ where the biogas manure was more efficient in this respect. The effectiveness of filter cake in increasing available $\mathrm{N}$ and $\mathrm{P}$ content in the studied soils could be attributed to its high content of these nutrient as compared with the biogas manure. 
Table 4. Effect of application of biogas manure and filter cake as a natural organic amendments on the available nutrient contents $\left(\mathrm{mg} \mathrm{kg}^{-1}\right)$ of a desertic soils.

a: Available nitrogen content

\begin{tabular}{|c|c|c|c|c|c|c|c|c|}
\hline \multirow{4}{*}{$\begin{array}{c}\text { Organic } \\
\text { amendment }(O)\end{array}$} & \multicolumn{8}{|c|}{ Available nitrogen content (mg kg ${ }^{-1}$ soil) } \\
\hline & \multicolumn{4}{|c|}{ Soil (1) } & \multicolumn{4}{|c|}{ Soil (2) } \\
\hline & \multicolumn{8}{|c|}{ Rates of addition $(\mathbf{R})$} \\
\hline & $\mathbf{R}_{\mathbf{0}}$ & $\mathbf{R}_{1}$ & $\mathbf{R}_{2}$ & Mean & $\mathbf{R}_{\mathbf{0}}$ & $\mathbf{R}_{1}$ & $\mathbf{R}_{2}$ & Mean \\
\hline $\mathbf{O}_{1}$ & 64.00 & 66.68 & 88.67 & 73.12 & 41.33 & 46.33 & 58.33 & 48.66 \\
\hline $\mathbf{O}_{2}$ & 64.00 & 88.67 & 106.33 & 86.33 & 41.33 & 45.67 & 69.67 & 52.22 \\
\hline Mean & 64.00 & 77.68 & 97.50 & & 41.33 & 46.00 & 64.00 & \\
\hline LSD at $5 \%$ & $\mathbf{O}=10.70$ & $\mathbf{R}=9.50$ & $\mathbf{O} \times \mathbf{R}=18.50$ & & $\mathrm{O}=\mathbf{1 . 3 0}$ & $\mathbf{R}=\mathbf{1 . 2 9}$ & $\mathbf{O} \times \mathbf{R}=$ & \\
\hline
\end{tabular}

See footnotes of Table $3 \mathrm{a}$.

b: Available phosphorus content

\begin{tabular}{|c|c|c|c|c|c|c|c|c|}
\hline \multirow{4}{*}{$\begin{array}{c}\text { Organic } \\
\text { amendment }(O)\end{array}$} & \multicolumn{8}{|c|}{ Available phosphorus content(mg kg-1 soil) } \\
\hline & \multicolumn{4}{|c|}{ Soil (1) } & \multicolumn{4}{|c|}{ Soil (2) } \\
\hline & \multicolumn{8}{|c|}{ Rates of addition $(\mathbf{R})$} \\
\hline & $\mathbf{R}_{\mathbf{0}}$ & $\mathbf{R}_{1}$ & $\mathbf{R}_{2}$ & Mean & $\mathbf{R}_{\mathbf{0}}$ & $\mathbf{R}_{1}$ & $\mathbf{R}_{2}$ & Mean \\
\hline $\mathbf{O}_{1}$ & 6.13 & 11.42 & 17.64 & 11.73 & 8.48 & 14.44 & 20.83 & 14.58 \\
\hline $\mathbf{O}_{2}$ & 6.13 & 24.15 & 26.88 & 19.05 & 8.48 & 25.18 & 31.53 & 21.73 \\
\hline Mean & 6.13 & 17.79 & 22.26 & & 8.48 & 19.81 & 26.18 & \\
\hline LSD at 5\% & $\mathbf{O}=1.30$ & $\mathbf{R}=1.20$ & $\mathbf{O} \times \mathbf{R}=2.30$ & & $\mathbf{O}=1$. & $\mathbf{R}=\mathbf{1}$ & O $\times$ R & \\
\hline
\end{tabular}

See footnotes of Table $3 a$

c: Available potassium content

\begin{tabular}{|c|c|c|c|c|c|c|c|c|}
\hline \multirow{4}{*}{$\begin{array}{c}\text { Organic } \\
\text { amendment }(\mathbf{O})\end{array}$} & \multicolumn{8}{|c|}{ Available potassium content $\left(\mathrm{mg} \mathrm{kg}^{-1}\right)$} \\
\hline & \multicolumn{4}{|c|}{ Soil (1) } & \multicolumn{4}{|c|}{ Soil (2) } \\
\hline & \multicolumn{8}{|c|}{ Rates of addition ( $\mathbf{R})$} \\
\hline & $\mathbf{R}_{\mathbf{0}}$ & $\mathbf{R}_{1}$ & $\mathbf{R}_{2}$ & Mean & $\mathbf{R}_{\mathbf{0}}$ & $\mathbf{R}_{1}$ & $\mathbf{R}_{2}$ & Mean \\
\hline $\mathbf{O}_{1}$ & 602 & 627 & 681 & 637 & 499 & 564 & 682 & 582 \\
\hline $\mathbf{O}_{2}$ & 602 & 648 & 655 & 635 & 499 & 509 & 550 & 519 \\
\hline Mean & 602 & 638 & 668 & & 499 & 536 & 616 & \\
\hline LSD at $5 \%$ & $\mathbf{O}=15$ & $\mathbf{R}=13$ & $\mathbf{O} \times \mathbf{R}=20$ & & $\mathbf{O}=20$ & $\mathbf{R}=18$ & $\mathbf{O} \times \mathbf{R}=25$ & \\
\hline
\end{tabular}

\section{2- Effect on physical properties:}

a. Effect on total porosity, pore size distribution and bulk density.

Effect on total porosity (TP)

The effect of applying the natural organic amendments under study on the total porosity of the studied soils is shown in Table $\mathbf{5}$.

Results in Table 5 show the effect of application of the natural organic amendments on total porosity. The main effect of the rate of application of the natural organic amendments under study, to the sandy loam soil (S1) show that TP significantly and progressively increased with increasing the rate of application. However, the increase in total porosity due to the application of R1 (1\%) was higher than that obtained due to the application of R2 (2\%) and there was no significant difference between the two rates. There was no significant difference between the two amendments in increasing the total porosity of the soil. However, there was an interaction effect between the rate of application and the kind of the amendment, where the application of the biogas manure increased the total porosity of the soil with increasing the rate of application, and the increase was significant only with the application of R2 (2\%) compared with R0 ( $0 \%$ ); and there was significant difference between R1 and R2; whereas the application of filter cake (filter mud) significantly increased the total porosity of soil 1 with increasing the rate of application. However, the increase due to the application of R1 (1\%) was higher than that obtained due to R2 (2\%) application.

Concerning the loamy sand soil (S2), the main effect of the rate of application show that total porosity increased due to the application of R1 (1\%) , however the increase was not significant. There was a significant difference between the two amendments, where the value of total porosity obtained due to the application of biogas manure was higher than that obtained due to the application of filter cake (filter mud) and significant. On the other hand, the interaction between the kind of amendment and the rate of application show that application of the biogas manure at R1 (1\%) and R2 (2\%) increased the total porosity of the soil under consideration as compared with R0, however the 
increase was significant only at R1 of application, whereas the application of filter cake decreased the total porosity with increasing the rate of application from R0 up to R2; the decrease was not significant and was higher at R1 than at R2.
The increase in total porosity due to the application of the biogas manure compared with filter cake may be due to its high content of clay and organic matter which act as a cementing agent between soil particles and caused aggregation of these particles, and consequently increases soil porosity.

Table 5. Effect of application of biogas manure and filter cake as a natural organic amendments on the total porosity $(\%)$ in a desertic soils.

\begin{tabular}{|c|c|c|c|c|c|c|c|c|}
\hline \multirow{4}{*}{$\begin{array}{c}\text { Organic } \\
\text { amendment }(O)\end{array}$} & \multicolumn{8}{|c|}{ Total porosity (TP) \% } \\
\hline & \multicolumn{4}{|c|}{ Soil (1) } & \multicolumn{4}{|c|}{ Soil (2) } \\
\hline & \multicolumn{8}{|c|}{ Rates of addition ( $R$ ) } \\
\hline & $\mathbf{R}_{\mathbf{0}}$ & $\mathbf{R}_{1}$ & $\mathbf{R}_{2}$ & Mean & $\mathbf{R}_{\mathbf{0}}$ & $\mathbf{R}_{1}$ & $\mathbf{R}_{2}$ & Mean \\
\hline 01 & 47.90 & 49.13 & 55.81 & 50.94 & 30.60 & 39.67 & 32.91 & 34.39 \\
\hline $\mathbf{O 2}$ & 47.90 & 57.44 & 49.95 & 51.76 & 30.60 & 27.68 & 28.12 & 28.80 \\
\hline Mean & 47.90 & 53.28 & 52.88 & & 30.60 & 33.67 & 30.51 & \\
\hline LSD at $5 \%$ & $\mathbf{O}=\mathbf{n . S}$ & $\mathbf{R}=\mathbf{2 . 0 7}$ & $\mathrm{O} \times \mathrm{R}=2.92$ & & $O=2.78$ & $\mathbf{R}=\mathbf{n . S}$ & $O \times R=4.82$ & \\
\hline
\end{tabular}

\section{Effect on pores size distribution:}

Results in Table 6a show that application of biogas manure and filter cake, at increased rate, to the soils under study, significantly decreased quickly drainable pores percent (QDP \%) in the sandy loam soil (S1) especially at R1(1\%) of application then significantly increased it at R2 (2\%) of application, whereas, significantly decreased it in the loamy sand soil, and the highest decrease occurred at R2 $(2 \%)$ of application. The decrease in the QDP percent could be attributed to that the fine particles of the applied amendment precipitated between the soil particles and hence decreased the volume of the soil pores. The decrease in QDP percent in the such soil is desirable for saving water for plants.

The main effect of the organic amendments show that there was a significant difference between the two amendments, where in the case of the sandy loam soil (S1) the application of the biogas manure significantly increased QDP \%, whereas the application of filter cake significantly decreased the QDP \%. The increase in the QDP percent in a such soil is desirable for increasing water drainage from the soil since its high content of $\mathrm{CaCO}_{3}$ reduce water movement due its swelling. In the case of the loamy sand soil (S2) the application of both amendments significantly decreased the QDP \%. However, the decrease due to the application of filter cake was higher than that obtained due to the application of biogas manure.

There was an interaction effect between the kind of the applied amendment and its rate of application. In the case of the sandy loam soil (S1), application of biogas manure significantly increased the QDP \% with increasing the rate of application from R0 up to R2, whereas, application of filter cake significantly decreased the QDP \% at R1 and significantly increased it at R2 of application. In the case of the loamy sand soil (S2), application of biogas manure significantly increased the QDP \% at R1 whereas significantly decreased it at R2 of application. On the other hand, application of filter cake the same trend occurred in the sandy loam soil (S1).

Concerning the effect of the studied organic amendments on slowly drainable pores percent (SDP $\%$ ), the main effect of the application rate (Table 6b) shows that, in the sandy loam soil (S1) it significantly increased with increasing the rate of application, whereas, in loamy sand soil (S2) it significantly increased at R1 then decreased at R2 of application.

The main effect of organic amendment application shows that there was a significant difference between the two amendments in the sandy loam soil (S1), where the application of filter cake significantly increased SDP \% more than the biogas manure. On the other hand, there was no significant difference between the two amendments in the case of the loamy sand soil (S2); however, the SDP \% obtained due to the application of biogas manure was higher than that obtained due to the application of filter cake.

The interaction effect between the kind of organic amendment and the rate of application shows that application of biogas manure to the sandy loam soil (S1) significantly decreased the SDP \% in the soil especially at R1 where the lowest SDP \% was obtained, whereas, the application of filter cake to the same soil significantly increased the SDP \% and the highest SDP \% was obtained at R1 of application.

As for the effect of the organic amendments on the water holding pores percent (WHP \%), results in Table 6c show the main effect of the rate of application and the main effect of organic amendments application. The main effect of the rate shows that application of the two organic amendments at increased rate significantly increased the WHP \% with increasing the application rate. However, in the sandy loam soil (S1) the highest WHP \% was obtained under R2 of application and there was no significant difference between R1 and R2; while in the loamy sand soil, the highest WHP \% 
was obtained under R1 of application and there was significant difference between R1 and R2.

The main effect of the organic amendments application (Table 6c) shows that there was no significant difference between the two studied amendments on increasing the WHP \% in the sandy loam soil (S1) and the highest WHP \% was obtained due to the application of the biogas manure. However, in the loamy sand soils (S2) there was a significant difference between the two amendments and the filter cake gave the highest WHP $\%$.

There was a significant interaction effect between the kind of the applied amendment and its rate of application on WHP \%, where in the sandy loam soil (S1) the biogas manure gave the highest WHP \% at R2 application, whereas, filter cake gave the highest WHP \% at R1 application. However, in the loamy sand soil (S2), both amendments gave the highest WHP \% at R1 of application.

Respect the effect on the fine capillary pores percent (FCP \%), results in Table 6d show that application of both biogas manure and filter cake, at increased rate, to the sandy loam soil (S1) decreased the FCP \% in the soil and the lowest FCP \% was obtained at R1. On the other hand, application of both amendments to the loamy sand soil (S2) significantly increased the FCP \% in the soil and the highest FCP $\%$ was obtained under R2 application. There was a significant difference between the rates of application.

The main effect of the amendment (Table 6d) shows that there was a significant difference between the two amendments in decreasing the FCP \% in the sandy loam soil (S1), where the FCP \% obtained due to the application of filter cake was lower than that obtained due to the application of biogas manure. On the other hand, there was no significant difference between the two amendments in increasing the FCP $\%$ in the loamy sand soil (S2).

There was a significant interaction effect between the organic amendment and the rate of application to the sandy loam soil (S1), where application of biogas manure significantly decreased the FCP \% in the soil at R1 then significantly increased it at R2 of application, whereas application of filter cake decreased the FCP \% with increasing the rate of application and the decrease was more pronounced at $\mathrm{R} 2$ than at R1)

Table 6 : Effect of application of biogas manure and filter cake as a natural organic amendments on the pore size distribution in a desertic soils.

a : Quickly drainable pores

\begin{tabular}{|c|c|c|c|c|c|c|c|c|}
\hline \multirow{4}{*}{$\begin{array}{c}\text { Organic } \\
\text { amendment }(0)\end{array}$} & \multicolumn{8}{|c|}{ Quickly drainable pores (QDP \%) } \\
\hline & \multicolumn{4}{|c|}{ Soil (1) } & \multicolumn{4}{|c|}{ Soil (2) } \\
\hline & \multicolumn{8}{|c|}{ Rates of addition ( $R$ ) } \\
\hline & $\mathbf{R}_{\mathbf{0}}$ & $\mathbf{R}_{1}$ & $\mathbf{R}_{2}$ & Mean & $\mathbf{R}_{\mathbf{0}}$ & $\mathbf{R}_{1}$ & $\mathbf{R}_{2}$ & Mean \\
\hline O1 & 20.75 & 24.20 & 28.10 & 24.35 & 25.35 & 31.75 & 4.33 & 20.48 \\
\hline $\mathbf{O 2}$ & 20.75 & 4.31 & 28.18 & 17.74 & 25.35 & 10.01 & 13.10 & 16.15 \\
\hline Mean & 20.75 & 14.25 & 28.14 & & 25.35 & 20.88 & 8.71 & \\
\hline LSD at $5 \%$ & $O=1.40$ & $\mathbf{R}=\mathbf{1 . 7 2}$ & $\mathbf{O} \times \mathbf{R}=2$ & & $\mathbf{O}=1.7$ & $\mathbf{R}=\mathbf{2 . 1 2}$ & $\times R=2$ & \\
\hline
\end{tabular}

\section{b : Slowly drainable pores}

\begin{tabular}{|c|c|c|c|c|c|c|c|c|}
\hline \multirow{4}{*}{$\begin{array}{c}\text { Organic } \\
\text { amendment }(O)\end{array}$} & \multicolumn{8}{|c|}{ Slowly drainable pores (SDP \%) } \\
\hline & \multicolumn{4}{|c|}{ Soil (1) } & \multicolumn{4}{|c|}{ Soil (2) } \\
\hline & \multicolumn{8}{|c|}{ Rates of addition ( $R$ ) } \\
\hline & $\mathbf{R}_{\mathbf{0}}$ & $\mathbf{R}_{1}$ & $\mathbf{R}_{2}$ & Mean & $\mathbf{R}_{\mathbf{0}}$ & $\mathbf{R}_{1}$ & $\mathbf{R}_{2}$ & Mean \\
\hline 01 & 0.68 & 0.24 & 0.46 & 0.46 & 0.56 & 2.12 & 0.65 & 1.11 \\
\hline $\mathbf{O 2}$ & 0.68 & 9.60 & 2.54 & 4.27 & 0.56 & 1.12 & 0.35 & 0.68 \\
\hline Mean & 0.68 & 4.92 & 1.50 & & 0.56 & 1.62 & $\mathbf{0 . 5 0}$ & \\
\hline LSD at $5 \%$ & $\mathrm{O}=0.19$ & $\mathbf{R}=\mathbf{0}$ & $10 \times R=$ & & $\mathbf{O}=\mathbf{n}$ & $\mathbf{R}=\mathbf{0 . 7}$ & $\mathbf{O} \times \mathbf{R}=$ & \\
\hline
\end{tabular}

See footnotes of Table $3 a$.

\section{c : Water holding pores}

\begin{tabular}{|c|c|c|c|c|c|c|c|c|}
\hline \multirow{4}{*}{$\begin{array}{c}\text { Organic } \\
\text { amendment }(O)\end{array}$} & \multicolumn{8}{|c|}{ Water holding pores (WHP \%) } \\
\hline & \multicolumn{4}{|c|}{ Soil (1) } & \multicolumn{4}{|c|}{ Soil (2) } \\
\hline & \multicolumn{8}{|c|}{ Rates of addition ( $R$ ) } \\
\hline & $\mathbf{R}_{\mathbf{0}}$ & $\mathbf{R}_{1}$ & $\mathbf{R}_{2}$ & Mean & $\mathbf{R}_{\mathbf{0}}$ & $\overline{\mathbf{R}_{1}}$ & $\mathbf{R}_{2}$ & Mean \\
\hline O1 & 21.65 & 24.77 & 28.66 & 25.03 & 5.16 & 14.84 & 6.92 & 8.97 \\
\hline $\mathbf{O 2}$ & 21.56 & 27.39 & 24.89 & 24.64 & 5.16 & 16.64 & 14.26 & 12.02 \\
\hline Mean & 21.65 & 26.08 & 26.78 & & 5.16 & 15.74 & 10.59 & \\
\hline LSD at $5 \%$ & $\mathrm{O}=\mathbf{0 . 9 3}$ & $R=1.14$ & $\mathbf{O} \times \mathbf{R}=\mathbf{n . S}$ & & $\mathrm{O}=0.98$ & $\mathbf{R}=\mathbf{1 . 1 9}$ & $\mathbf{O} \times \mathbf{R}=$ & \\
\hline
\end{tabular}

See footnotes of Table $3 a$. 


\section{d : Fine capillary pores}

\begin{tabular}{|c|c|c|c|c|c|c|c|c|}
\hline \multirow{4}{*}{$\begin{array}{c}\text { Organic } \\
\text { amendment }(O)\end{array}$} & \multicolumn{8}{|c|}{ Fine capillary pores (FCP \%) (WP) } \\
\hline & \multicolumn{4}{|c|}{ Soil (1) } & \multicolumn{4}{|c|}{ Soil (2) } \\
\hline & \multicolumn{8}{|c|}{ Rates of addition $(\mathbf{R})$} \\
\hline & $\mathbf{R}_{\mathbf{0}}$ & $\mathbf{R}_{1}$ & $\mathbf{R}_{2}$ & Mean & $\mathbf{R}_{\mathbf{0}}$ & $\mathbf{R}_{1}$ & $\mathbf{R}_{2}$ & Mean \\
\hline 01 & 2.76 & 1.92 & 3.40 & 2.69 & 0.33 & 0.39 & 0.54 & $\mathbf{0 . 4 2}$ \\
\hline $\mathbf{O 2}$ & 2.76 & 2.01 & 0.68 & 1.82 & 0.33 & 0.28 & 0.55 & 0.39 \\
\hline Mean & 2.76 & 1.96 & 2.04 & & 0.33 & $\mathbf{0 . 3 3}$ & 0.55 & \\
\hline LSD at $5 \%$ & $\mathrm{O}=0.53$ & $\mathbf{R}=\mathbf{n} . \mathbf{S}$ & $\mathbf{O} \times \mathbf{R}=0.90$ & & $\mathbf{O}=\mathbf{n . s}$ & $\mathbf{R}=\mathbf{0 . 1 3}$ & $\mathbf{O} \times \mathbf{R}=\mathbf{n . s}$ & \\
\hline
\end{tabular}

See footnotes of Table 3a.

\section{Effect on bulk density (Bd):}

Results in Table 7 show the effect of the applied organic amendments on the bulk density $(\mathrm{Bd})$ of the studied soils. The main effect of the application rate shows that the bulk density of the sandy loam soil (S1) significantly decreased with increasing the rate of application especially at R2, whereas that of the loamy sand soil significantly increased with increasing the rate of application and the highest $\mathrm{Bd}$ value was obtained at R2 of application.

The main effect of the organic amendment shows that there was a significant difference between the two amendments in the sandy loam soil (S1) only, where the application of biogas manure decreased soil bulk density more than filter cake and the decrease was significant.
There was an interaction effect between the kind of the amendment and its rate of application. In the case of the sandy loam soil (S1) application of biogas manure slightly increased $\mathrm{Bd}$ at $\mathrm{R} 1$ of application then decreased it at R2 of application, whereas application of filter cake significantly decreased $\mathrm{Bd}$ at $\mathrm{R} 2$ and there was no difference between Bd obtained at R0 1n R1 of application. In the case of the loamy sand soil (S2), application of biogas manure significantly decreased its $\mathrm{Bd}$ at $\mathrm{R} 1$ and significantly increased it at R2 of application and visa versa occurred with the application of filter cake. The decrease in soil $\mathrm{Bd}$ could be attributed to the increase in soil porosity occurred due to the applied amendment which cause the aggregation of soil particles producing stable aggregates and hence increase soil porosity and decrease soil $\mathrm{Bd}$.

Table 7 . Effect of application of biogas manure and filter cake as a natural organic amendments on the Bulk density $\left(\mathrm{Mg} / \mathrm{m}^{3}\right)$ of a desertic soils.

\begin{tabular}{|c|c|c|c|c|c|c|c|c|}
\hline \multirow{4}{*}{$\begin{array}{c}\text { Organic } \\
\text { amendment }(O)\end{array}$} & \multicolumn{8}{|c|}{ Bulk density $\left(\mathrm{Mg} / \mathrm{m}^{3}\right)$} \\
\hline & \multicolumn{4}{|c|}{ Soil (1) } & \multicolumn{4}{|c|}{ Soil (2) } \\
\hline & \multicolumn{8}{|c|}{ Rates of addition ( $R$ ) } \\
\hline & $\mathbf{R}_{\mathbf{0}}$ & $\mathbf{R}_{1}$ & $\mathbf{R}_{2}$ & Mean & $\mathbf{R}_{\mathbf{0}}$ & $\mathbf{R}_{1}$ & $\mathbf{R}_{2}$ & Mean \\
\hline O1 & 1.01 & 1.02 & 0.94 & 0.99 & 1.29 & 1.26 & 1.40 & 1.31 \\
\hline $\mathbf{O 2}$ & 1.01 & 1.01 & 0.99 & 1.00 & 1.29 & 1.37 & 1.28 & 1.31 \\
\hline Mean & 1.01 & 1.01 & 0.97 & & 1.29 & 1.31 & 1.34 & \\
\hline LSD at $5 \%$ & $\mathrm{O}=0.01$ & $\mathbf{R}=\mathbf{0 . 0 1}$ & $\mathbf{O} \times \mathbf{R}$ & & $\mathbf{O}=\mathbf{n}$. & $\mathbf{R}=\mathbf{0 . 0 1}$ & $\mathbf{O} \times \mathbf{R}=$ & \\
\hline
\end{tabular}

\section{b. Effect on moisture content (\%) at field capacity (FC), wilting point (WP) and available water (Av.w) content:}

Results in Table 8a, $8 b$ and $8 c$ show the effect of application of the studied amendments on the moisture content $(\%)$ at field capacity (FC), wilting point (WP) and the available water (Av.w) content, respectively.

Concerning the moisture content at field capacity, the main effect of the rate of application (Table 8a) shows that moisture content at field capacity, in both soils under study, significantly increased with increasing the application rate of both amendments. There was no significant difference, in soil moisture content at FC, between R1 and R2 in the case of the sandy loam soil (S1) whereas a significant difference, in soil moisture content at FC, occurred between R1 and R2 in the case of the loamy sand soil (S2).
The main effect of the kind of organic amendment (Table 8a) shows that there was a significant difference, in soil moisture content at FC in both soils under study, between biogas manure and filter cake. In the case of the sandy loam soil (S1), application of biogas manure and filter significantly increased soil moisture content at field capacity, however, soil moisture content at field capacity due to the application of biogas manure was higher than that obtained due to the application of filter cake. In the case of loamy sand soil (S2), visa versa occurred, where, filter cake application increased its FC more higher than biogas manure.

There was an interaction effect between the kind of the amendment and the rate of application. In the case of the sandy loam (S1) application of biogas manure significantly and progressively increased its FC with increasing the rate of application, whereas, 
application of filter cake significantly and progressively increased its FC with increasing the rate of application, but, the increase was higher at R1 than at R2. In the case of the loamy sand soil (S2), application of both amendments under study significantly and progressively increased its moisture content at FC and the increase at R1 of application was more higher than that obtained at R2 of application.

As for the effect of the applied organic amendments on soil moisture content at wilting point and the available water content in both soils under study, results in Tables $8 \mathrm{~b}$ and $8 \mathrm{c}$ show that the effect of application of both of the two studied amendments on soil moisture content at wilting point and the available water content in both soils take the same behavior and effect occurred with the FCP $\%$ and WHP \%, where, physically soil moisture content at wilting point equal to soil moisture content retained in the FCP and the available water content equal to soil moisture content retained in WHP.

Table 8 . Effect of application of biogas manure and filter cake as a natural organic amendments on moisture content (\%) at field capacity (FC), wilting point (WP) and available water (Av.w) content of a desertic soils.

a : Field capacity:

\begin{tabular}{|c|c|c|c|c|c|c|c|c|}
\hline \multirow{3}{*}{$\begin{array}{c}\text { Organic } \\
\text { amendment }(O)\end{array}$} & \multicolumn{8}{|c|}{ Moisture content at $0.33 \%$ bar (FC) } \\
\hline & \multirow{2}{*}{\multicolumn{3}{|c|}{ Soil (1) }} & & \multicolumn{4}{|c|}{ Soil (2) } \\
\hline & & & & \multicolumn{5}{|c|}{ Rates of addition ( $R$ ) } \\
\hline & $\mathbf{R}_{\mathbf{0}}$ & $\mathbf{R}_{1}$ & $\mathbf{R}_{2}$ & Mean & $\mathbf{R}_{\mathbf{0}}$ & $\mathbf{R}_{1}$ & $\mathbf{R}_{2}$ & Mean \\
\hline 01 & 24.41 & 26.69 & 32.06 & 27.72 & 5.49 & 15.23 & 7.46 & 9.39 \\
\hline $\mathbf{O 2}$ & 24.41 & 29.40 & 25.57 & 26.46 & 5.49 & 16.92 & 14.81 & 12.41 \\
\hline Mean & 24.41 & 28.04 & 28.13 & & 5.49 & 16.08 & 11.13 & \\
\hline LSD at $5 \%$ & $\mathrm{O}=0.27$ & $\mathbf{R}=\mathbf{0 . 3 2}$ & $\mathbf{O} \times \mathbf{R}=$ & & $\mathbf{O}=\mathbf{1}$ & $\mathbf{R}=\mathbf{2 . 3}$ & $\mathbf{O} \times \mathbf{R}=$ & \\
\hline
\end{tabular}

b : Wilting point

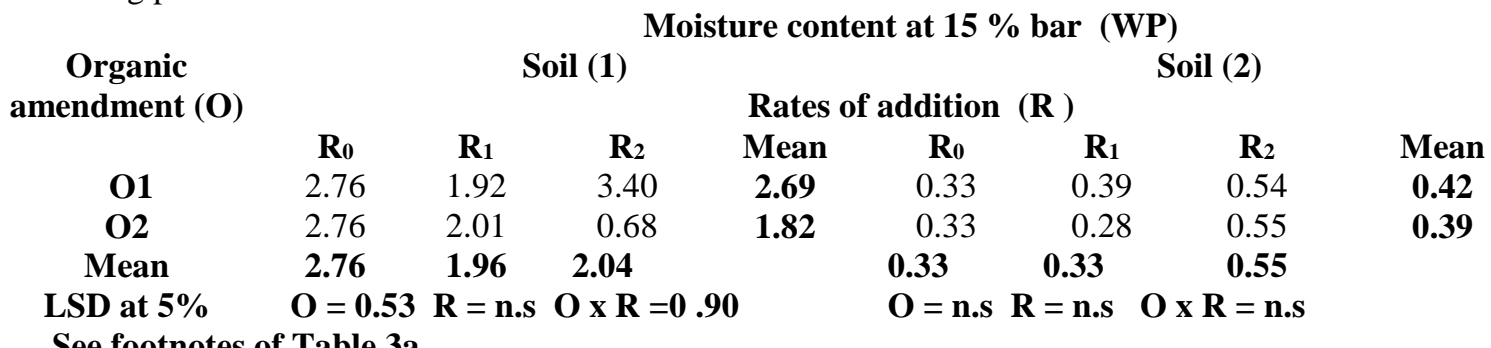

c : Available water

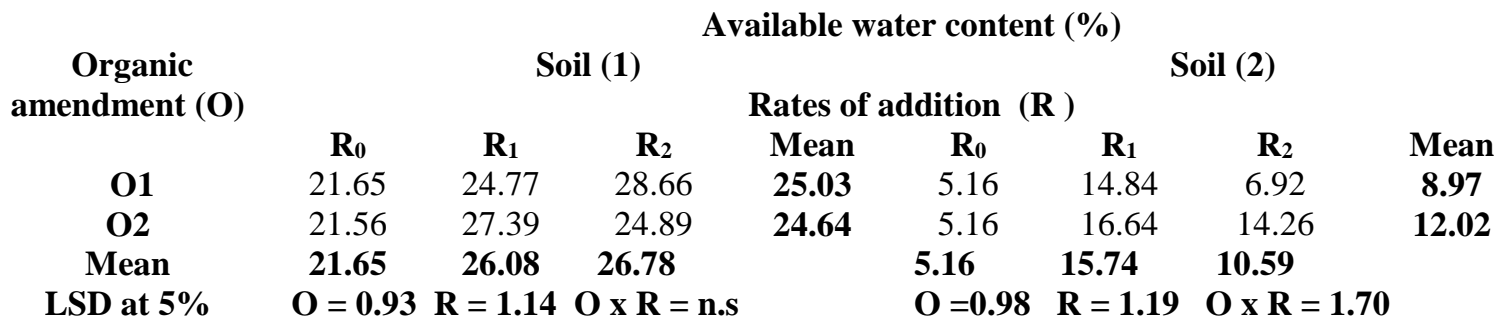

\section{Conclusion}

It could be concluded that application of biogas manure and filter cake improved the majority of soil properties and the improvement depends on the properties of the applied amendment, the application rate and the native soil properties. Filter cake was more efficient than the biogas manure in improving soil properties.

\section{References}

Abubakar, S. D., and N. B. Eniolorunda. 2016. Effect of desertification on some selected soil properties in a semi arid part of Northwestern Nigeria. Journal of Geoscience and Environment Protection, 4: 111-123.

Aksakal, E. L., I. Angin, and T. Oztas. 2012. Effects of diatomite on soil physical properties. Catena, 88: $1-5$.

Aldabaa, A. A., H. Zhang, A. Shata, S. El-Sawey, A. Abdel-Hameed, and J. L. Schroder. 2010. Land sutability classification of desert area in Egypt for some crops using Microleis program. American-Eurasian J. Agric. \&Environ. Sci., 8(1): 80-94. 
Ali, W.H. 2013. Suitability of Egyptian deserts for sustainable urban development. Developing Country Studies, 3(8).

Balba, A., 1989. Management of problem soils in arid ecosystems. Dar El- Matbouat Al- Gadedah, Alex. Egypt.

Brady, N.C. 1990. The Nature and properties of soils, ninth ed. Macmillian Publishing, New York.

Bush, R. 2007. Politics, power and poverty: twenty years of agricultural reform and market liberalisation in Egypt. Third World Quarterly, 28 (8): 1599-1615.

Campbell, D.J., J.V. Stafford, and P.S. Blackwell. 2002. The plastic limit, as determined by the dropcone test, in relation to the mechanical behavior of soil. J. Soil Sci., 31: 11-24.

D'Odorico, P., A. Bhattachan, K.F. Davis, S. Ravi, and C.W. Runyan. 2012. Global desertification: drivers and feedbacks. Advances in Water Resources, 51: 326-344.

Dregne, H.E. 2002. Land degradation in the dry lands. Arid Land Research and Management, 16: 99-132.

EEAA. 2007.. 2007. Egypt Environmental Profile. Egyptian Environmental Affairs Agency (EEAA) [Online] Available: http://www.eeaa.gov.eg/english/main/envprofile .asp

El-Banna, M. N., M. A. Abd El-Gawad, M. N. Mohamed, and M. A. El. Boseely. 2011. Evaluation of 16 barley genotypes under calcareous soil conditions in Egypt. Journal of Agricultural Science, 3 (1): 105-121.

El-Hady, O.A., and S.A. Abou-Sedera. 2006. The conditioning effect of composts (natural) or/and acrylamide hydrogels (synthesized) on a sandy calcareous soil. II. Chemical and biological properties of the soil. Egypt. J.Soil Sci., 43: 538546.

Foth, H.D. 1990. Fundamentals of soil science. 8 Ed. John Wiley and Sons. New York, USA. th 5.

Gad, A., and S. Abdel-Samie. 2000. Study on desertification of irrigated arable lands in Egypt. Egypt. J. Soil Sci., 40 (3): 373-384.

Gray, L.C. 1999. Is land being degraded? A multiscale investigation of landscape change in southern Burkina Faso. Land Degrad. Develop., 10:329-343.

Klute, M. 1986. Methods soil analysis. Part1. Physical and Mineralogical Methods $2^{\text {nd }}$ Ed. Am.

Misak, R.F., J.M. Al-Awadhi, S.O. Omar, and S.A. Shahid. 2002. Soil degradation in Kabd, Southwestern Kuwait city. Land Degrad. Develop., 13:403-415.

Nyamangara, J., J. Gotosa and S.E. Mpofu. 2001. Cattle manure effects on structural stability and water retention capacity of a granitic sandy soil in Zimbabwe. Soil and Tillage Res., 62: 157-162.

Page, A.L., R. H. Miller and D.R. Keeney 1982. Methods of soil analysis. Part 2: Chemical and Microbiological Properties. Second edition. Agronomy J. 9: 2, Am. Soc. Agron. Inc., Soil Sci. Soc. Am. Inc. Pub. Madison, Wisconsin, USA.

Ravi, S., D.D. Breshears, T.E. Huxman, and D. D'Odorico. 2010. Land degradation in drylands: interactions among hydrologic-aeolian erosion and vegetation dynamics. Geomorphology, 116: 236-245.

Snedicor, G. W. and W. G. Cochran. 1980. Statistical Methods, 6th ed. Iowa State Univ. Press, Iowa, USA.Soc. of Agr., Inc., Soil Sci. Soc. of Am., Inc Madison, Wisconsin, USA., $399-404$.

Tewari, V.P. and R. Arya. 2005. Degradation of arid rangelands in Thar desert, India: A Review. Arid Land Research and Management, 19: 1-12.

UNCCD. 1994. United Nations convention to combat desertification in countries experiencing serious Drought and/or desertification, Particularly in Africa. A/AC.241/27, Paris.

Tejada, M., and J.L. Gonzalez. 2004. Effects of application of a byproduct of the two-step olive oil mill process on maize yield. Agron. J. 96, 692699.

Watson, C. A., D. Atkinson, P. Gosling, L. R. Jackson, and F. W. Rayns. 2002. Managing soil fertility in organic farming systems. Soil Use Manage., 18: 239-247.

Wessels, K.J., S.D. Prince, and I. Reshef. 2008. Mapping land degradation by comparison of vegetation production to spatially derived estimates of potential production. Journal of Arid Environments, 72: 1940-1949.

Wessels, K.J., S.D. Prince, J. Malherbeb, J. Small, P.E. Frost, and D. VanZyl. 2007. Can humaninduced land degradation be distinguished from the effects of rainfall variability? A Case Study in South Africa. Journal of Arid Environments, 68: 271-297.

Yangyuoru, M., E. Boateng, S.G.K. Adiku, D. Acquah, T.A. Adjadeh, and F. Mawunya, 2006. Effects of natural and synthetic soil conditioners on soil moisture retention and maize yield. West Africa J. Applied Ecol., 9: 1-8.

Yilmaz, E., and Z. Alagöz. 2010. Effects of shortterm amendements of farmyard manure on some soil properties in the Mediterranean region Turkey.

Zia, M.S. 1993. Soil fertility evaluation and management for flooded lowland rice soils of Pakistan. Ph. D. Dissertation, Kyoto University, Japan. 


\title{
تأثير إضافة روث الغاز الحيوى ( سماد البيوجاز) وطينة التصفية على تحسين بعض خواص الاراضى الصحراوية وتداعيتها على النبات النامى عليها.
}

\author{
1 - التأثير على الخواص الكيميائية والطبيعية للتربة

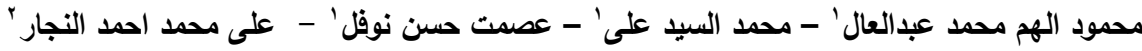

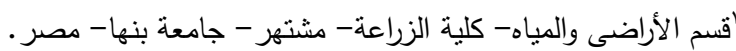

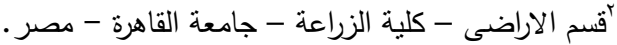

Filter cake or filter مئف البحث الحالي إلى دراسة تأثثر إضافة روث الغاز الحيوي (Biogas manure) وطينة التصفية

عud mud تحسين بعض خصائص التربة الصحراوية وآثارها على النباتات المزروعة عليها. لتحقيق هذه الأهداف جُمعت عينة من التربة السطحية ( · - . - سم) من منطقة الحمام، الساحل الثمالي الغربي لهصر من أرضين صحراويتين تختلفان في القوام وفى محتواها من كربونات الكالسيوم، لتنثيل الأراضى الصحراوية.

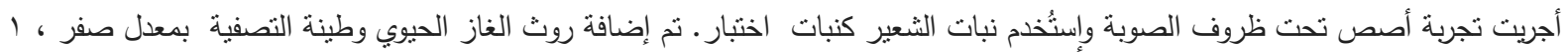

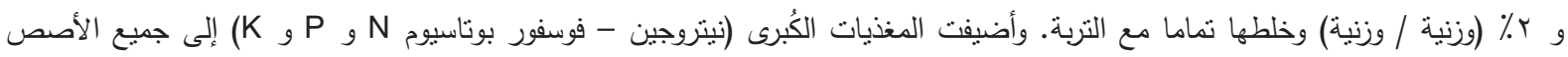

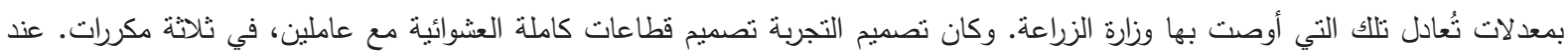

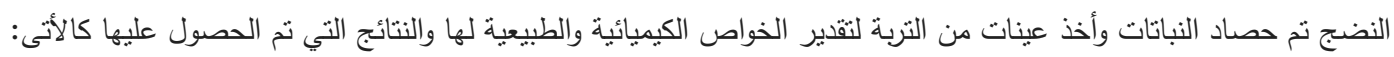
1. أظهر التأثير الرئيسي (الثاثير العام) لمعدل إضافة روث الغاز الحيوي (biogas manure) وطينة التصفية (Filter cake or Filter mud) إلى التربة الرملية اللومية (التربة () أن ملوحة التربة انخفضت معنوياً عند معدل الإضافة R1 (1 \% ) بينما زادت قليلا عند معدل الإضافة

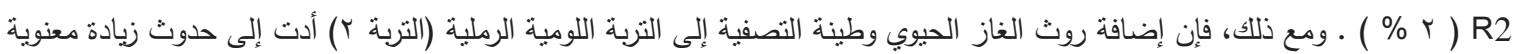

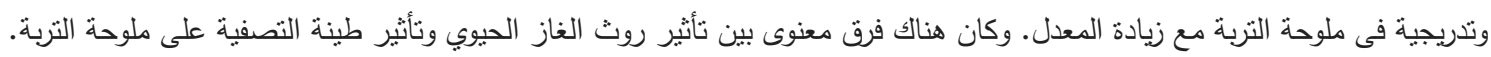

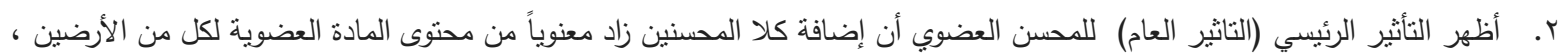

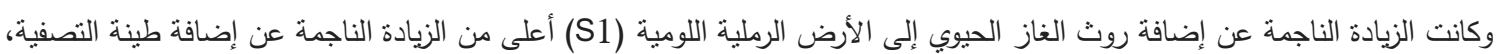
والعكس بالعكس حدث في حالة التربة اللومية الرملية (S2).

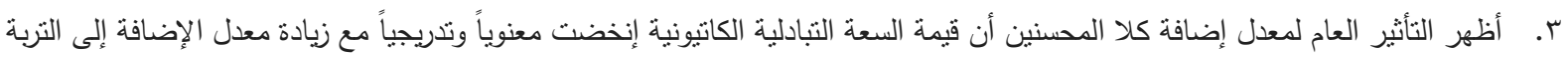

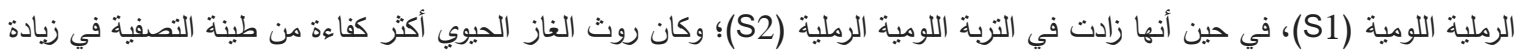
قايمة السعة التبادلية الكانيونية للتربة.

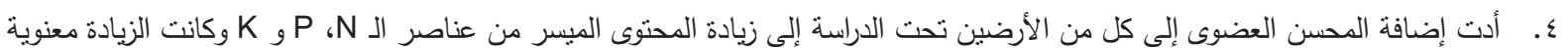

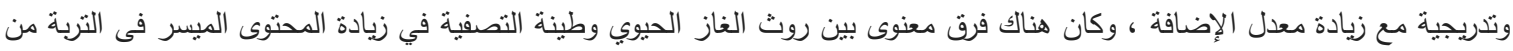

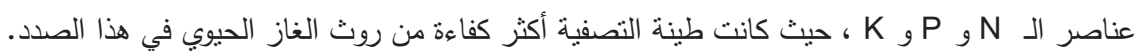

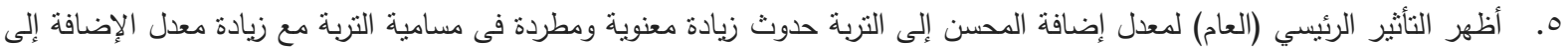

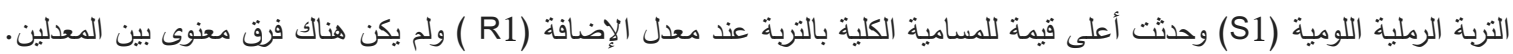

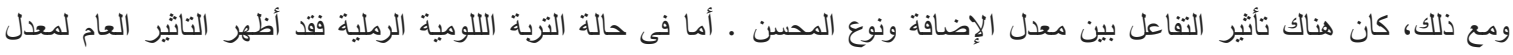

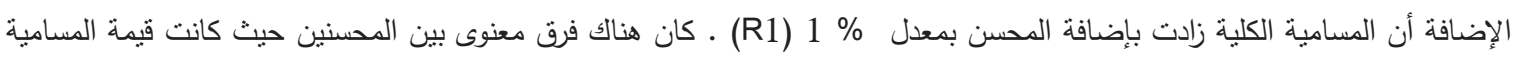
الكلية التي تم الحصول عليها نتيجة إضافة روث الغاز الحيوي أعلى من تلك التي تم الحصول عليها بسبب إضافة طينة التصفية إلى كلا

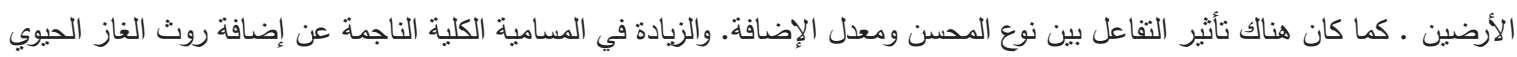
مقارنة مع طينة التصفية وقد تكون بسبب محتواه العالي من الطين والمواد العضوية التي تعمل كمادة لاحمة بين حبييات التربة وتسبب تجميعها

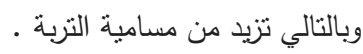
4. كان لإضافة المحسنات الددروسة تأثير إيجابي على التزيع الحجمى للمسام في الأراضى تحت الدراسة حيث أدت إضافتها إلى التربة الرملية

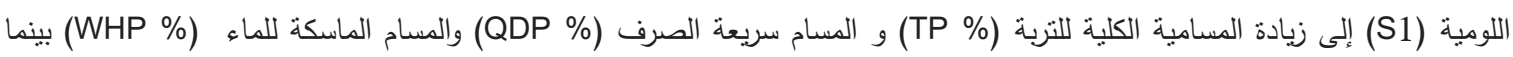

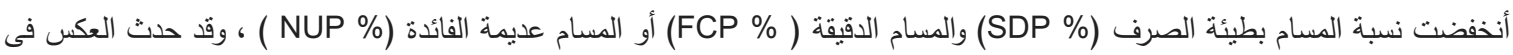
الأرض اللومية الرملية (S2). كما أدت إضافة كلا الدحنين إلى الأراضى تحت الدراسة إلى زيادة المحتوى الرطوبى للنزبة عند السعة 
الحقلية والمحتوى المائي الميسر (الماء الميسر للنبات) في حين أن رطوبة التربة إنخفتث عند نقطة الذبول في التربة الرملية اللومية (S1)

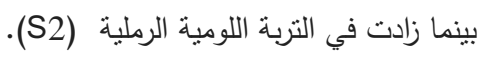

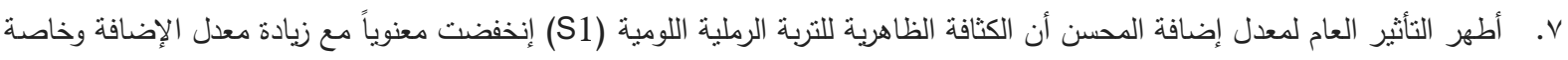
عند إضافة المعدل R2، في حين أنها زادت معنوياً فى الأرض اللومية الرملية مع زيادة معدل الإضافة و تم الحصول على أعلى العلى قيمة للكثافة

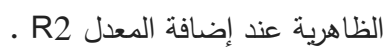

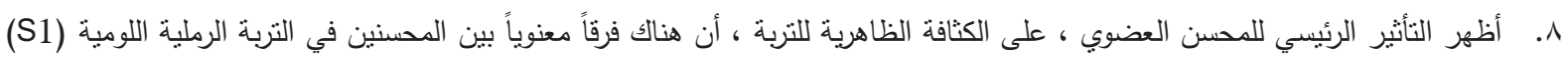

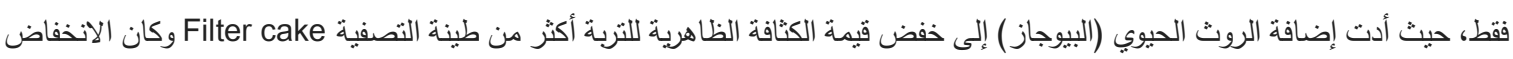

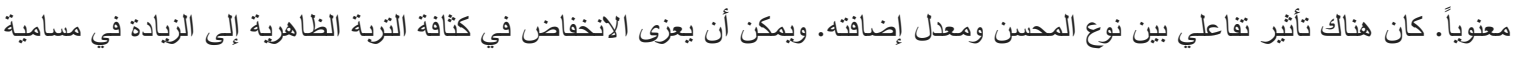

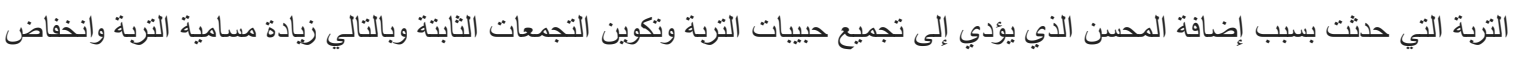

من النتائج المتحصل عليها يمكن إستتناج أن إضافة روث الغاز الحيوى (سماد البيوجاز) وطينة التصفية حسنت معظم صفات أو خواص الأرضين

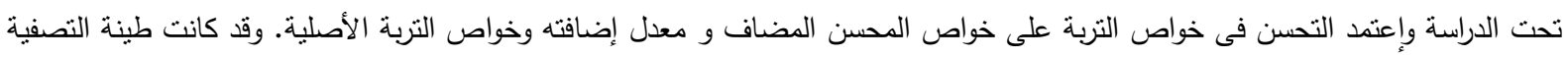

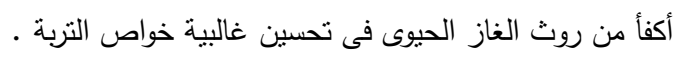


